\title{
THE SUSTAINABLE PERFORMANCE OF THE DIGITAL START-UP COMPANY BASED ON CUSTOMER PARTICIPATION, INNOVATION, AND BUSINESS MODEL
}

\author{
Pri Agung DANARAHMANTO ${ }^{1 *}$, Ina PRIMIANA ${ }^{2}$, Yudi AZIS ${ }^{3}$, Umi KALTUM ${ }^{4}$ \\ ${ }^{1}$ Akademi Perekam Medis dan Informatika Kesehatan Bandung, Bandung, Indonesia \\ 2, 3, ${ }^{4}$ Faculty of Economics and Business, Universitas Padjadjaran, Bandung, Indonesia
}

Received 13 August 2019; accepted 04 December 2019

\begin{abstract}
The digital-based start-up industry in Indonesia has developed, but with a high failure rate. This research aims at elaborating the relationship between business model, entrepreneurial orientation, innovation, and sustainable performance on the digital start-up companies in Indonesia. The data were collected using offline and online surveys to 206 leaders or founders of digital start-up companies spread throughout Indonesia. Then, the data were then analysed using the structural equation model. The research results revealed that a business model had a significant role in achieving sustainable performance. A business model needs to be supported by customer participation and innovation. Innovation was more influential compared to customer participation in achieving companies' sustainable performance. The indirect effect of customer participation and innovation on sustainable performance through the business model was greater than the direct effect not through the business model. The novelty of this research is the examination and analysis of the relationship between innovation, customer participation, business model, and sustainable performance in one model, and the use of digital start-up companies in Indonesia as the research analysis unit.
\end{abstract}

Keywords: business model, customer participation, digital startup, innovation, structural equation model, sustainable performance.

JEL Classification: M2, M15, O3.

\section{Introduction}

The development of digital technology is signified by the growth of various internet-based activities. This growth is followed by the establishment of new businesses in the digital sector known as the digital start-up. According to Blank (2010), a start-up is an organization that is still seeking for appropriate business form and model to obtain a measurable and repeatable business model.

The growth of digital start-up companies is accompanied by various challenges, such as the high failure rate of digital start-up companies. Allmand (2013) reported that $90 \%$ of start-up companies failed to thrive. This data was supported by the data released by Bandung Techno Park (BTP), as one of the incubators of digital start-up inIndonesia, as reported by Rahayu (2018), as the manager of business incubation in BTP, states that 75\% start-up companies failed to develop. CB Insight (2019) affirms that the failure of start-up companies is mostly caused by the use of an inappropriate business model.
Start-up companies have conducted various ways to survive, one of which is by designing new business models and carrying out various innovations. Schaltegger, Lüdeke-Freund, and Hansen (2012), Boons and Lüdeke-Freund (2013) define a business model as the conceptual structure that can encourage the achievement of a sustainable business. BTP (2018) states that even though digital start-up companies in Indonesia use business models to conduct various innovations, failures still occur due to the customers' lack of interest in products created, thus resulted in less profit.

The customers' unwillingness to buy a product is due to their expectation and needs that can be addressed by the companies' innovation products. The companies do not consider and involve the consumers in the process of product development (Rahayu, 2018). Meanwhile, utilizing customer participation is able to generate the value continuity of business (Merlo, Eisingerich, \& Auh, 2014).

${ }^{*}$ Corresponding author. E-mail: priagung.dana@gmail.com 
Based on the afore mentioned phenomenon, there is a gap between empirical theory and fact. Teece (2007) and Chang and Lee (2008) state that innovation can encourage the achievement of sustainable performance, and LüdekeFreund (2013) state that business model has a vital role in achieving sustainable performance. However, empirically, many startup companies have failed to develop despite having a business model and carrying out various innovations.

Therefore, this research seeks to test the effect of business model mediation on innovation and customer participation toward the sustainable performance of digital start-up companies in Indonesia. In the previous research, these three variables were examined out separately. Meanwhile, this research contributes to a better understanding of the establishment of a business model based on innovation and customer participation in digital start-up companies in Indonesia.

This research is composed of several parts. The first part is the review of relevant literature and the development of the theoretical framework and hypothesis. The second is the explanation of the methodology and data collection. The third is the data analysis and discussion. The final part is the conclusion and implication of this research.

\section{Literature review and hypotheses}

\subsection{Innovation}

In general, innovation is related to change. Drucker (1985) considers innovation as an opportunity to change the business to obtain different products and services. In addition, innovation can be defined as changes in the organization responding to environmental changes (Damanpour, 1996).

Innovation is also defined as an implementation of activities in ways different from the existing conditions or norms (Afuah \& Tucci, 2001). In addition to being achieved through the introduction of new products and services, and new methods of production, distribution, or marketing, innovation can also be achieved through activity approach, transaction structure, or business model (Zott \& Amit, 2001).

Companies keep changing and innovating to compete and survive in a competitive environment (Merx-Chermin \& Nijhof, 2005). There are many beneficial innovation activities that can be performed by companies with inadequate capitals (Lendel \& Varmus, 2013). Start-up companies are considered new and can be categorized as small companies. Small companies have innovative character that can boost the business performance (Rahman et al., 2016). They can change by innovating in various aspects. Rademakers (2005) states that innovation can be conducted on several aspects, such as product, process, organization, and business. Innovation can also be conducted by doing changes in the organization, marketing, process, and product (Gunday et al., 2011).

\subsection{Customer participation}

Customer participation can be defined as the extent of the customers' involvement in the process of new product development (Fang, 2008). According to Mustak et al. (2013), customer participation refers to customer activity regarding the provision of either tangible or intangible resources to develop and create offers. Merlo et al. (2014) suggest that customer participation is the customers' role in providing constructive suggestions and ideas to help companies produce product and service.

Several previous research reported that companies can utilize customer participation in various aspects, such as in creating ideas and concepts (Joshi \& Sharma, 2004), in conducting tests (Lagrosen, 2005), and in conducting distribution (Dabholkar, 2015). In the current digital era, customer participation in promoting products is considered significant. The customers are expected to play a role as co-marketers (Gouthier \& Schmid, 2003; Chervonnaya, 2003) who will be useful for promoting or reviewing the products and services so that they can draw other people.

Customer participation is essential for companies in achieving sustainable competitive advantages (Fang, 2008). On the other hand, customer participation can also decelerate the companies' performance. According to Chang and Taylor (2016), customer participation in the process of product development will slow down the process and worsen company's performance, while customer participation at the stage of making product ideas can increase company's performance through an acceleration of production time.

\subsection{Business model}

A business model is an architecture describing product, service, information, business people, profit, and source of revenue (Timmers, 1998). Magretta (2002) defines a business model as a conceptual framework used to describe customers, value given to customers, how to generate revenue, and how to convey value to customers. A business model can also be defined as business guidance. According to Teece (2010), a business model is used to guide the company in running a business and in fulfilling the customers' need.

Research on business model has been conducted by several researchers. Osterwalder's (2004) research regarding components of business models resulted in the nine building blocks of a business model. Zott and Amit (2007) researched on how to design a business model on technology-based companies resulted in two types of business model designs, namely the noveltybased business model and the efficiency-based business model. The efficiency-based business model referred to how companies achieve efficiency to reduce transaction costs for all participants related to the companies. Meanwhile, the novelty-based business model referred to the new methods in carrying out the economic exchange between participants.

\subsection{Sustainable performance}

According to the United Nations (1987), sustainability is defined as an effort to fulfill the current needs by 
considering the conditions of fulfilling the needs in the future. Sustainability is the present and future views relating to the economy, social, and environment (Elkington, 1998).

Sustainability is often used as references for the success of companies, one of which is by trying to achieve sustainable performance. Hall, Deneke, and Lenox (2010) defines that sustainable performance is an effort to maintain social, environmental, and economic sustainability considering the conditions in the present and the future. Sustainable performance is also associated with innovation in the start-up companies producing beneficial products and services to the environment and/or society (Wijnker, Van Kasteren, \& Romijn, 2015).

Financial factors and non-financial factors are the two determinants in the achievement of sustainable performance. Teeratansirikool et al. (2012) state that financial conditions are more influential on companies compared to the non-financial ones. This statement is supported by Santos and Brito (2012) stating that financial performance is significantly related to profitability and growth, compared to other variables.

\subsection{Relationship between innovation, customer participation, business model, and sustainable performance}

Previous research showed that there was a relationship between customer participation, business model, and sustainable performance. Customer participation is related to the value establishment in the company's business model (Prahalad \& Ramaswamy, 2004; Plé, Lecocq, \& Angot, 2010). Customer participation can also encourage companies to redesign business models, one of which is by adjusting the way companies obtain profits from customers (Merlo et al., 2014).

The establishment of a business model is also influenced by other aspects, namely innovation. Innovation can affect changes in the companies' revenue streams and profits (Sinfield et al., 2012). When innovation occurs, it is necessary to adjust the business model, such as in the delivery of value to the customers (Teece, 2010). This opinion is supported by Baden-Fuller and Haefliger (2013) stating that technological developments and innovations encourage changes in business models that affect changes in how companies make money and profits.

Several studies suggested that business models could influence companies' sustainable performance (Schaltegger et al., 2012; Boons \& Lüdeke-Freund, 2013). As stated by Redis (2009), a component of the business model affecting sustainable performance was revenue streams. This statement is supported by Teeratansirikool et al. (2012) stating that the companies' financial condition affected performance, and it can be used to predict the companies' condition in the future.

Other studies showed that sustainable performance was also related to innovation and customer participation. Innovation was required to deal with changes so that companies can achieve sustainable performance (Teece, 2007). Innovation was useful for companies to lead the market and maintain business (Chang \& Lee, 2008). Other research stated that customer participation helped generating sustainable value for business (Merlo et al., 2014). Customers also played a role in product development to improve company performance (Chang \& Taylor, 2016).

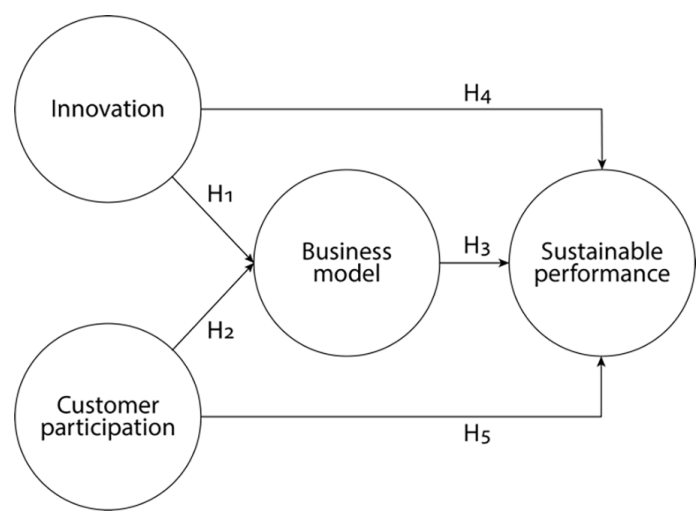

Figure 1. Research model

Based on the description, the proposed hypotheses in this research are, as follows.

H1: Innovation influences the business model of digital start-up companies in Indonesia.

$\mathrm{H} 2$ : Customer participation influences the business model of digital start-up companies in Indonesia.

H3: Business model influences the sustainable performance of digital start-up companies in Indonesia.

H4: Innovation influences the sustainable performance of digital start-up companies in Indonesia.

H5: Customer participation influences the sustainable performance of digital start-up companies in Indonesia.

\section{Methodology}

This research employed explanatory research with a quantitative approach using the structural equation model (SEM). The sampling technique used was stratified random sampling in several regions in Indonesia. The observation unit of the sample in this research was leaders or founders of digital start-up companies in Indonesia. This research involved digital startup companies with limitations based on the definition of digital start-up issued by the Indian government in 2017, which are companies that have been running for less than seven years, have total revenues of less than Rupee 25 crores or equal to fifty billion Rupiah and working towards innovation (Ministry of Commerce and Industry of the Republic of India, 2017). The definition was chosen because Indonesia has not had official criteria on the digital start-up yet. Moreover, Indonesia and India are Asian countries that have almost similar economic levels. Furthermore, research that employed SEM should at least involve 200 respondents (Shah \& Goldstein, 2006) and it is not recommended to have less than 200 respondents (Barrett, 2007), hence the samples 
of this research were 206 leaders or founders of digital startup companies in Indonesia.

This research seeks to test the relationship of innovation, customer participation, and model business on sustainable performance. In specific, the sustainable performance is seen from the company perspectives on economy, company environment, and social, which are in accordance with research done by Schaltegger et al. (2012). These criteria were chosen since digital start-up companies are new, hence their focus is on the efforts to survive by paying attention to the economy, environment, and social conditions of the company, since the companies have not paid much attention to the environment preservation.

The tests in this research were carried out using SEM that began with a model measurement test by using confirmatory factor analysis in order to see the suitability of endogenous and exogenous constructs in this research to the model fit test. The tests were also conducted to assess the path, thus that direct and indirect effects could be identified on the research model.

Data collection was carried out by survey using an online questionnaire. The questions represented the indicators used to explore dimensions of research variables. The responses were classified on a Likert scale of six-point responses using the ordinal scale. The six-point scale was used to reduce the level of bias in the responses to the questionnaire results (Cummins \& Gullone, 2000), in addition, the six-point scale has a high level of reliability (Chomeya, 2010). Hypothesis testing was conducted with the help of AMOS 23.0 software. The dimensions and indicators in this research were used to measure innovation, customer participation, business models, and sustainable performance that are presented in Table 1.

Table 1. Variables, dimension and indicators of the study

\begin{tabular}{|c|c|c|}
\hline Variable & Dimension & Indicator \\
\hline \multirow[t]{12}{*}{ Innovation } & \multirow{3}{*}{$\begin{array}{l}\text { Organi- } \\
\text { zation } \\
\text { innovation }\end{array}$} & $\begin{array}{l}\text { Changes in organizational } \\
\text { structure }\end{array}$ \\
\hline & & Changes in procedure \\
\hline & & $\begin{array}{l}\text { Changes in supply chain } \\
\text { management system }\end{array}$ \\
\hline & \multirow{3}{*}{$\begin{array}{l}\text { Marketing } \\
\text { innovation }\end{array}$} & New marketing tool \\
\hline & & New promotion technique \\
\hline & & New product pricing \\
\hline & \multirow{3}{*}{$\begin{array}{l}\text { Process } \\
\text { innovation }\end{array}$} & Changes in variable cost \\
\hline & & $\begin{array}{l}\text { Changes in production output } \\
\text { quality }\end{array}$ \\
\hline & & $\begin{array}{l}\text { Changes in activities that have } \\
\text { no added value }\end{array}$ \\
\hline & \multirow[t]{3}{*}{$\begin{array}{l}\text { Product } \\
\text { innovation }\end{array}$} & $\begin{array}{l}\text { New products to increase } \\
\text { customer satisfaction }\end{array}$ \\
\hline & & $\begin{array}{l}\text { New products with new } \\
\text { functionality }\end{array}$ \\
\hline & & $\begin{array}{l}\text { New product quality } \\
\text { improvement }\end{array}$ \\
\hline
\end{tabular}

End of Table 1

\begin{tabular}{|c|c|c|}
\hline Variable & Dimension & Indicator \\
\hline \multirow[t]{9}{*}{$\begin{array}{l}\text { Customer } \\
\text { participation }\end{array}$} & \multirow{3}{*}{$\begin{array}{l}\text { Customer } \\
\text { partici- } \\
\text { pation } \\
\text { as an } \\
\text { informa- } \\
\text { tion } \\
\text { resource }\end{array}$} & $\begin{array}{l}\text { Customer activities in providing } \\
\text { market situation }\end{array}$ \\
\hline & & $\begin{array}{l}\text { Customer activities in providing } \\
\text { information for development } \\
\text { team }\end{array}$ \\
\hline & & $\begin{array}{l}\text { Customer activities in } \\
\text { channelling information }\end{array}$ \\
\hline & \multirow{3}{*}{$\begin{array}{l}\text { Customer } \\
\text { partici- } \\
\text { pation } \\
\text { as a co- } \\
\text { developer }\end{array}$} & $\begin{array}{l}\text { Customer activities in creating } \\
\text { new product }\end{array}$ \\
\hline & & $\begin{array}{l}\text { Customer activities in finishing } \\
\text { product }\end{array}$ \\
\hline & & $\begin{array}{l}\text { Customer activities in co- } \\
\text { development }\end{array}$ \\
\hline & \multirow{3}{*}{$\begin{array}{l}\text { customer } \\
\text { partici- } \\
\text { pation } \\
\text { as a co- } \\
\text { marketer }\end{array}$} & $\begin{array}{l}\text { Customer activities in spreading } \\
\text { product information }\end{array}$ \\
\hline & & $\begin{array}{l}\text { Customer activities in reviewing } \\
\text { product }\end{array}$ \\
\hline & & $\begin{array}{l}\text { Customer activities in } \\
\text { influencing other customers }\end{array}$ \\
\hline \multirow[t]{6}{*}{$\begin{array}{l}\text { Business } \\
\text { model }\end{array}$} & \multirow{3}{*}{$\begin{array}{l}\text { Efficiency } \\
\text { business } \\
\text { model }\end{array}$} & $\begin{array}{l}\text { Business model offers process } \\
\text { efficiency }\end{array}$ \\
\hline & & $\begin{array}{l}\text { Business model offers ease of } \\
\text { transaction }\end{array}$ \\
\hline & & $\begin{array}{l}\text { Business model offers easy } \\
\text { exchange of information }\end{array}$ \\
\hline & \multirow[t]{3}{*}{$\begin{array}{l}\text { Novel } \\
\text { business } \\
\text { model }\end{array}$} & $\begin{array}{l}\text { Business model offers new } \\
\text { combinations of products, } \\
\text { services, and information }\end{array}$ \\
\hline & & $\begin{array}{l}\text { Business model brings together } \\
\text { new participants }\end{array}$ \\
\hline & & Business model is novel \\
\hline \multirow[t]{15}{*}{$\begin{array}{l}\text { Sustainable } \\
\text { performance }\end{array}$} & \multirow{3}{*}{$\begin{array}{l}\text { Cost } \\
\text { and cost } \\
\text { reduction }\end{array}$} & $\begin{array}{l}\text { Energy saving when producing } \\
\text { products }\end{array}$ \\
\hline & & $\begin{array}{l}\text { Cost reduction to increase } \\
\text { profits }\end{array}$ \\
\hline & & Production cost efficiency \\
\hline & \multirow{3}{*}{$\begin{array}{l}\text { Sales and } \\
\text { profit } \\
\text { margin }\end{array}$} & Producing profitable products \\
\hline & & Revenue diversification \\
\hline & & $\begin{array}{l}\text { Company profit for operational } \\
\text { needs }\end{array}$ \\
\hline & \multirow{3}{*}{$\begin{array}{l}\text { Risk } \\
\text { and risk } \\
\text { reduction }\end{array}$} & Reduce social risk \\
\hline & & Raise debt ratings \\
\hline & & $\begin{array}{l}\text { Obtain resources for the } \\
\text { company's needs }\end{array}$ \\
\hline & \multirow{3}{*}{$\begin{array}{l}\text { Reputation } \\
\text { and brand } \\
\text { value }\end{array}$} & $\begin{array}{l}\text { Marketing features to increase } \\
\text { customer loyalty }\end{array}$ \\
\hline & & $\begin{array}{l}\text { Company's performance to } \\
\text { ensure the sustainability of funds }\end{array}$ \\
\hline & & $\begin{array}{l}\text { Company's ability to maintain } \\
\text { reputation }\end{array}$ \\
\hline & \multirow{3}{*}{$\begin{array}{l}\text { Attrac- } \\
\text { tiveness as } \\
\text { employer }\end{array}$} & $\begin{array}{l}\text { Ability to offer and add value for } \\
\text { employee }\end{array}$ \\
\hline & & $\begin{array}{l}\text { Ability to maintain employee } \\
\text { motivation }\end{array}$ \\
\hline & & $\begin{array}{l}\text { Ability to be an attractive } \\
\text { company }\end{array}$ \\
\hline
\end{tabular}




\section{Result}

\subsection{Respondent description}

The majority of the respondents were male (87.38\%) who were under 30 years old (65.05\%). The respondents were classified as highly educated as they had an undergraduate education or higher $(82.53 \%)$. This indicated that the leaders or founders of the start-up companies in this research had a high level of education and better thinking skills. Details of the respondents' profile are presented in Table 2.

Table 2. Respondent description

\begin{tabular}{|c|c|c|}
\hline Respondent profile & Freq $(\mathrm{n})$ & $\%$ \\
\hline \multicolumn{3}{|l|}{ Gender } \\
\hline Male & 180 & 87.38 \\
\hline Female & 26 & 12.62 \\
\hline \multicolumn{3}{|l|}{ Age } \\
\hline$<30$ years & 134 & 65.05 \\
\hline $30-45$ years & 68 & 33.01 \\
\hline$>45$ years & 4 & 1.94 \\
\hline \multicolumn{3}{|l|}{ Education } \\
\hline Doctoral & 3 & 1.46 \\
\hline Postgraduate & 41 & 19.90 \\
\hline Graduate & 126 & 61.17 \\
\hline Diploma & 8 & 3.88 \\
\hline High school & 28 & 13.59 \\
\hline
\end{tabular}

\subsection{Validity and reliability}

Validity measurement can be conducted by looking at the value of construct reliability (CR) and average variance extracted (AVE). CR and AVE are calculated after calculating the value of standardized regression weight. If the value of standardized loading $(\lambda)$ is more than 0.50 , it is considered to have validity strong enough to explain the construct. While construct reliability is a measure of the consistency from the indicators that shows the degree in the variable, and variance extracted is a measure of the amount of indicator variance extracted by the variable. The value of CR is considered good if the value $>0.70$, while the value of AVE considered good if the value $>$ 0.50 (Hair et al., 2010). The result of measurement model test for exogenous and endogenous constructs can be seen from the coefficient values of the loading factor for each indicator presented in Table 3.

The value of standardized loading $(\lambda)$ of all items in this research construct was $>0.50$, which can be concluded that the construct was valid. The values of AVE and CR for all constructs were also valid because all the values of $\mathrm{CR}>0.70$, and the value of AVE $>0.50$. Based on the calculation, the standardized loading, CR, and AVE requirements were fulfilled, thus all exogenous and endogenous constructs had acceptable construct validity and reliability (Hair et al., 2010).

\subsection{Hypotheses testing}

\section{Structural model}

The model measurement was carried out to see the level of conformity of the relationship between the four constructs namely customer participation, innovation, business models, and sustainable performance. Based on the calculation using AMOS 23.0 software, the goodness of fit criteria values were obtained from the structural equation model of this research. Based on the calculation, the result of chi-square $=79.902$ with $\mathrm{p}$-value $=0.174$, the model was considered as fit due to the p-value $>0.05$; Goodness of Fit Index $(\mathrm{GFI})=0.950$, the model was also considered as fit due to the value of GFI $\geq 0.90$; Adjusted Goodness of Fit $(\mathrm{AGFI})=0.924$, the model was considered as fit

Table 3. Measurement of endogenous and exogenous constructs

\begin{tabular}{|c|c|c|c|c|c|c|}
\hline Construct & Items & $\lambda$ & $\lambda^{2}$ & $\mathrm{e}$ & CR & AVE \\
\hline \multirow{4}{*}{ Innovation } & Organization innovation & 0.806 & 0.650 & 0.350 & \multirow{4}{*}{0.915} & \multirow{4}{*}{0.731} \\
\hline & Marketing innovation & 0.850 & 0.723 & 0.278 & & \\
\hline & Process innovation & 0.935 & 0.874 & 0.126 & & \\
\hline & Product innovation & 0.822 & 0.676 & 0.324 & & \\
\hline \multirow{3}{*}{$\begin{array}{l}\text { Customer } \\
\text { Participation }\end{array}$} & Cust as information resources & 0.965 & 0.931 & 0.069 & \multirow{3}{*}{0.908} & \multirow{3}{*}{0.768} \\
\hline & Cust as co-developer & 0.858 & 0.736 & 0.264 & & \\
\hline & Cust as co-marketer & 0.797 & 0.635 & 0.365 & & \\
\hline \multirow{2}{*}{ Business Model } & Efficiency & 0.798 & 0.637 & 0.363 & \multirow{2}{*}{0.763} & \multirow{2}{*}{0.616} \\
\hline & Novel & 0.772 & 0.596 & 0.404 & & \\
\hline \multirow{5}{*}{$\begin{array}{l}\text { Sustainable } \\
\text { Performance }\end{array}$} & Cost and cost reduction & 0.787 & 0.619 & 0.381 & \multirow{5}{*}{0.879} & \multirow{5}{*}{0.596} \\
\hline & Sales and Profit margin & 0.585 & 0.342 & 0.658 & & \\
\hline & Risk and risk reduction & 0.799 & 0.638 & 0.362 & & \\
\hline & Reputation and brand value & 0.818 & 0.669 & 0.331 & & \\
\hline & Attractiveness as employer & 0.843 & 0.711 & 0.289 & & \\
\hline
\end{tabular}


due to the AGFI value $\geq 0.80$; the Comparative Fit Index $(\mathrm{CFI})=0.995$, the model was considered as fit due to the CFI value $\geq 0.90$; the Tucket-Lewis Index $(\mathrm{TLI})=$ 0.993, the model was considered as fit due to the GFI value $\geq 0.90$; and the Root Mean Square Error of Approximation $($ RMSEA $)=0.028$, the model was considered as fit due to the RMSEA value $\leq 0.08$. Based on the literature, all values of the model fit are in an acceptable range (Hair et al., 2010, Ghozali, 2006).

The results of the relationship calculation between the constructs are presented in Table 4 and the path description in Figure 1. The t-value at $H 1(t=5.804), H 2(t=$ 3.531), H3 ( $t=8.066), H 4(t=4.147)$, and $H 5(t=2.343)$, and each path was greater than the $t$-table of 1.97 . Therefore, it can be concluded that $H 1, H 2, H 3, H 4$ and $H 5$ were supported because $\mathrm{t}$-count $>\mathrm{t}$-table.

Based on the relationship between variables, all constructs of the variables showed a significant relationship. The relationship between customer participation and innovation with the business model was positive with a total effect of $R^{2}=0.464$. It indicated that the business model was able to be explained by customer participation and innovation by $53.6 \%$, while $46.4 \%$ could be explained by other variables not examined in this research. Meanwhile, the relationship between customer participation, innovation, and business models on sustainable performance was positive with a total effect of $R^{2}=0.878$. It indicated that sustainable performance was able to be explained by customer participation and innovation by $87.8 \%$, while $12.2 \%$ was explained by other variables not examined in this research.

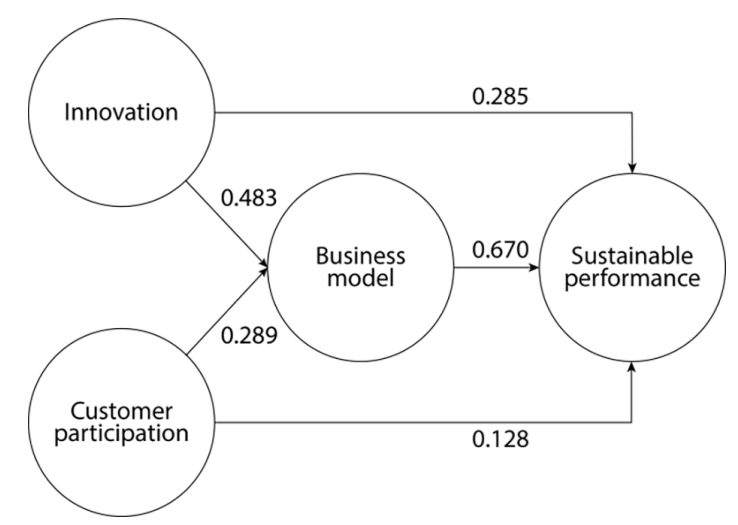

Figure 2. Research findings

\section{Direct and indirect effects}

Path selection was conducted by comparing the direct and indirect effects between each construct of variables, as seen in Figure 2. The direct relationship was able to be seen from the path coefficient, while the indirect relationship was calculated by multiplying the path coefficient contributed. The direct relationship between customer participation and sustainable performance was
0.128 . Meanwhile the indirect relationship between customer participation and sustainable performance through a business model of 0.194 was calculated by multiplying the customer participation coefficient to the business model (0.289) and the business model to sustainable performance $(0.670)$. The direct relationship between innovation and sustainable performance was 0.258. Meanwhile, the indirect relationship between innovation and sustainable performance through the business model was 0.324 calculated by multiplying the coefficient of innovation to the business model (0.483) and the business model to sustainable performance (0.670). When compared between direct and indirect effects, the path of the business model had a greater influence than the direct path without going through the business model. Based on the calculation results, the direct and indirect effects had a significant influence and showed the same direction, so it was able to be categorized as complementary mediation (Hair et al., 2014). Therefore, the business model had a function as an intervening variable in the influence between customer participation on sustainable performance and innovation on sustainable performance.

\section{Discussion}

The rapid growth of the start-up industry is also accompanied by a high failure rate of start-up companies. This research is aimed at gaining an understanding of the factors influencing companies' performance. This research examined the perspective of leaders or founders of startup companies on business models, innovation, and customer participation to support the achievement of sustainable performance. The leader of digital start-up companies involved in this research were dominated by male, since female tends to think that digital start-up companies focuses more on technical issues that are suitable done by male, hence, female do not want to get involved. In addition, the leader or founder of the company have obtained higher level of education, hence, they are considered to have good thinking ability in facing dynamic business competition. People with higher level of education have the abilities to think, solve problems, and make better decisions compared to those with lower education levels (Klein, 1999).

This research produced a structural model with a good level of fit. This showed that the business model had the most important role to encourage the creation of sustainable performance. The research results emphasized that the start-up companies' business model influenced sustainable performance, both in economic and non-economic terms (Boons \& Lüdeke-Freund, 2013). These results were in line with Lüdeke-Freund (2013), stating that business models had an important role in sustainability by creating social, ecological and economic value. Business models in companies keep changing to achieving continuity and sustainability (Schaltegger et al., 2012). 
Table 4. Path coefficients and t-value for the models

\begin{tabular}{|l|c|c|c|}
\hline \multicolumn{1}{|c|}{ Impact of } & $\begin{array}{c}\text { Path } \\
\text { coefficients }\end{array}$ & t-value & Result \\
\hline $\begin{array}{l}\text { H1: Customer } \\
\text { Participation } \rightarrow \text { Business } \\
\text { Model }\end{array}$ & $0.289^{*}$ & 3.531 & Supported \\
\hline $\begin{array}{l}\text { H2: Customer } \\
\text { Participation } \rightarrow \\
\text { Sustainable Performance }\end{array}$ & $0.128^{\star}$ & 2.343 & Supported \\
\hline $\begin{array}{l}\text { H3: Innovation } \rightarrow \\
\text { Business Model }\end{array}$ & $0.483^{\star}$ & 5.804 & Supported \\
\hline $\begin{array}{l}\text { H4: Innovation } \rightarrow \\
\text { Sustainable Performance }\end{array}$ & $0.258^{*}$ & 4.147 & Supported \\
\hline $\begin{array}{l}\text { H5: Business Model } \rightarrow \\
\text { Sustainable Performance }\end{array}$ & $0.670^{*}$ & 8.066 & Supported \\
\hline
\end{tabular}

Note: ${ }^{*}$ sig $<0.01, \mathrm{t}$-table $=1.97$, chi square $=79.902, \mathrm{GFI}=0.950$, AGFI $=0.924, \mathrm{CFI}=0.995, \mathrm{TLI}=0.993, \mathrm{RMSEA}=0.028$.

The research results revealed that the business model was influenced by several aspects, one of which was innovation, in start-up companies in Indonesia. This was because companies engaged in the digital sector encountered high uncertainty, and must continually strive to make changes, and adapt to market conditions, such as innovating in terms of product, process, marketing, and organization. The results of this research were in line with Chesbrough and Rosenbloom (2002), stating that innovation requires market adjustments and business models. Teece (2010) and Lee et al. (2012) revealed that when innovation occurred, it is necessary to change or adjust the business model to deliver value to customers. Other research conducted by Sinfield et al. (2012) stating that innovation influenced business models, and affected changes in revenue flows in business models.

The findings of this research indicated that another factor influencing the start-up companies' business model was customer participation. This supported Plé et al.s (2010) research results, stating that customer participation was able to encourage companies to make strategic decisions, such as redesigning business models. Customer participation also encouraged the interaction between components in the business model (Djelassi \& Decoopman, 2013). Customer participation affected the start-up companies' business model because in the current digital era, information can be easily accessed. Hence, the criticism, suggestions, comments, or desires from the customers could be received quickly and easily by the companies to be used as the consideration for making changes in the component models business.

The direct relationship had also a significant effect on customer participation and sustainable performance. This finding is consistent with the theoretical assumptions supporting this research as proposed by Merlo et al. (2014), explaining that customer participation helped producing sustainability for business. Other research stated that customer participation supported the achievement of sustainability and competitive advantage and financial performance (Fang, 2008). Several other research found that there was a relationship between customer participation and sustainable performance (Gouthier \& Schmid, 2003; Chang \& Taylor, 2016; Joo \& Shin, 2017). However, other research supported that customer participation had a positive effect on sustainable performance. According to Chang and Taylor (2016), customer participation decelerated and worsened the companies' performance on the product development process, because the involvement of customer desires could change in needs that delayed the completion of product development.

In addition to having a direct relationship with customer participation, sustainable performance also had a direct relationship with innovation. This finding is in line with Teece (2007), stating that innovation is needed to deal with changes so that companies are able to achieve sustainable performance. According to Schaltegger and Wagner (2011), innovation affected the sustainable performance of entrepreneurs or companies by observing changes in innovation and market changes over time. Other research conducted by Muhamad, Ebrahim, and Hami (2014) stated that there was a positive and significant relationship between innovation ability and economic, environmental and social sustainability, which was because the start-up companies competed in a very dynamic industry that they were required to keep innovating to achieve sustainable performance.

\section{Implications}

There are several implications obtained from the results of this research. This research can be used as a reference to examine the effect of customer participation, innovation, and business models on sustainable performance in digital start-up companies in Indonesia. The findings of this research provide knowledge about the effect of sustainable performance and business models on digital startup companies in Indonesia. The findings of this research can be used by digital start-up companies in Indonesia to achieve sustainable performance so that they can survive amid the intense business competition. Based on the understanding of the research findings, the business model in digital start-up companies had an important role to achieve sustainable performance. This research can help the founders or leaders of digital start-up companies to design beneficial business models to maintain the companies' sustainability.

The research findings indicated that digital start-up companies could achieve sustainable performance by implementing business models based on novelty and efficiency, which are supported by innovation and customer participation. This research revealed that in designing business models, the effect of innovation was higher than customer participation. This implies that a digital start-up is a company engaged in the dynamic digital industry, so it must frequently make innovations or changes to fulfill 
customers' expectations. The process, marketing, product, and organization of innovations carried out affected changes in business model design because the innovations required companies to make adjustments in business model components. For example, when a company innovates a product due to the adoption of new technology, there is a change in value (value proposition) offered to customers, even there may be an expansion or change in the market (customer segment) in the business model. Based on the customer participation's perspective, customer involvement in the company, as a source of information, co-developers, co-marketers, will affect changes in business models because the purpose of establishing a company is to fulfill customer needs. Therefore, customer input will encourage changes in business models to produce the output of companies in accordance with customers' needs and expectations.

The research results also revealed that innovation and customers participation directly influence the achievement of sustainable performance in digital start-up companies. Various changes and customer involvement in the companies are considered as the companies' step to understand and fulfill customer needs. This has to be done by the companies to be the customers' first choice. Therefore, that the customers want to buy the products or services provided by the company in order for the company to survive and develop sustainably.

This research showed that the indirect relationship of innovation and customer participation to sustainable performance through the business model had a greater value than the direct relationship without going through the business model. This indicates that the business model has an important role in encouraging the achievement of sustainable performance in digital start-up companies. Innovation and customer participation need to be facilitated in the business model to make it easier to plan, execute, and evaluate innovation and customer involvement in companies. If there is no intervening business model, innovation and customer participation in digital start-up companies tend to be unplanned.

This research can be used as a complement to the existing literature, especially related to business models, innovation, customer participation, and sustainable performance. In Indonesia, there has not been any research that involved these four variables simultaneously related to digital companies. Therefore, this research will certainly provide new theoretical insights into business models in digital start-up companies in Indonesia.

\section{Limitation and direction for future research}

This research has several limitations. First, this research examines companies located in Indonesia, so that there can be differences in interpretation of research results for companies located outside Indonesia, hence further research needs to be conducted. Second, this research does not describe the relationship between indicators and dimensions of variables in-depth. Based on the review and connection of constructs referring to several previous studies, this research results can be applied to countries that have similar conditions to Indonesia.

Many aspects influence the establishment of business models, one of which is entrepreneurial orientation. According to Bouncken, Lehmann, and Fellnhofer (2016), entrepreneurial orientation encourages the creation of value and proportion of value and encourages companies to make new business models or offers. Therefore, further research is expected to be able to study entrepreneurial orientation as support in establishing business models to achieve sustainable performance.

\section{Conclusions}

Previous scientific discussions argued that there is a relationship between innovation and customer participation in business models and sustainable performance partially. Meanwhile, this research offers another perspective and provides evidence that a business model plays a role as an intervening variable. In other words, innovation and customer participation encourage sustainable performance and/or through business models in digital start-up companies. Therefore, it is highly recommended for founders or leaders of digital start-up companies to build and implement novelty-based business models and innovation and customer participation-based efficiency. Further research on entrepreneurial orientation as a complement to innovation and customers participation to establish a business model encouraging sustainable performance, both in digital companies or in non-digital companies, are suggested to be conducted to constructive useful research and discussion.

\section{References}

Allmand, R. (2013, January 23). Mapping tech startups [Web log post]. allmandlaw.com/blog/2013/january/mapping-techstartups.aspx

Afuah, A., \& Tucci, C. (2001). Internet business models and strategies: text and cases. New York: McGraw-Hill Irwin.

Baden-Fuller, C., \& Haefliger, S. (2013). Business models and technological innovation. Long Range Planning, 46(6), 419426. https://doi.org/10.1016/j.lrp.2013.08.023

Barrett, P. (2007). Structural equation modelling: Adjudging model fit. Personality and Individual Differences, 42(5), 815824. https://doi.org/10.1016/j.paid.2006.09.018

Blank, S. (2010). What's a startup? First principles. https://steveblank.com/2010/01/25/whats-a-startup-first-principles/

Boons, F., \& Lüdeke-Freund, F. (2013). Business models for sustainable innovation: state-of-the-art and steps towards a research agenda. Journal of Cleaner Production, 45, 9-19. https://doi.org/10.1016/j.jclepro.2012.07.007

Bouncken, R. B., Lehmann, C., \& Fellnhofer, K. (2016). The role of entrepreneurial orientation and modularity for business model innovation in service companies. International Journal of Entrepreneurial Venturing, 8(3), 237-260. https://doi.org/10.1504/IJEV.2016.078973 
Rahayu, E. (2018). Data Tenant BTP [Microsoft Excel spreadsheet]. Bandung: Bandung Techno Park.

CB Insight. (2019). The Top 20 reasons startups fail [Research Brief]. https://www.cbinsights.com/research/startup-failurereasons-top/

Chang, S., \& Lee, M. (2008). The linkage between knowledge accumulation capability and organizational innovation. Journal of Knowledge Management, 12(1), 3-20. https://doi.org/10.1108/13673270810852359

Chang, W., \& Taylor, S. (2016). The effectiveness of customer participation in new product development: a meta-analysis. Journal of Marketing, 80(1), 47-64. https://doi.org/10.1509/jm.14.0057

Chervonnaya, O. (2003). Customer role and skill trajectories in services. International Journal of Service Industry Management, 14(3), 347-363. https://doi.org/10.1108/09564230310478864

Chesbrough, H., \& Rosenbloom, R. (2002). The role of the business model in capturing value from innovation: evidence from Xerox Corporation's technology spin-off companies. Industrial and Corporate Change, 11(3), 529-555. https://doi.org/10.1093/icc/11.3.529

Chomeya, R. (2010). Quality of psychology test between Likert scale 5 and 6 points. Journal of Social Sciences, 6(3), 399-403. https://doi.org/10.3844/jssp.2010.399.403

Cummins, R., \& Gullone, E. (2000, 8-10 March). Why we should not use 5-point Likert scales: The case for subjective quality of life measurement. In Proceeding of the 2nd international conference on quality of life in cities (pp. 74-93). Singapore.

Dabholkar, P. (2015). How to improve perceived service quality by increasing customer participation. In Proceedings of the 1990 Academy of Marketing Science (AMS) Annual Conference (pp. 483-487). New Orleans, Louisiana. Springer. https://doi.org/10.1007/978-3-319-13254-9_97

Damanpour, F. (1996). Organizational complexity and innovation: developing and testing multiple contingency models. Management Science, 42(5), 693-716. https://doi.org/10.1287/mnsc.42.5.693

Djelassi, S., \& Decoopman, I. (2013). Customers' participation in product development through crowdsourcing: Issues and implications. Industrial Marketing Management, 42(5), 683-692. https://doi.org/10.1177/2051570716650160

Drucker, P. (1985). Innovation and entrepreneurship. UK: Pan Business Management.

Elkington, J. (1998). Cannibals with forks: 1he triple bottom line 21 century business. Gabriela Island, British Columbia: New Society Publishers. https://doi.org/10.1002/tqem.3310080106

Fang, E. (2008). Customer participation and the trade-off between new product innovativeness and speed to market. Journal of Marketing, 72(4), 90-104.

https://doi.org/10.1016/j.ijpe.2011.05.014

Ghozali, I. (2006). Aplikasi Analisis Multivarite dengan SPSS. Semarang: Badan Penerbit Universitas Diponegoro.

Gouthier, M., \& Schmid, S. (2003). Customers and customer relationships in service firms: The perspective of the resourcebased view. Marketing Theory, 3(1), 119-143.

https://doi.org/10.1177/1470593103003001007

Gunday, G., Ulusoy, G., Kilic, K., \& Alpkan, L. (2011). Effects of innovation types on firm performance. International Journal of Production Economics, 133(2), 662-676. https://doi.org/10.1016/j.ijpe.2011.05.014

Hair, J., Black, W., Babin, B., Anderson, R., \& Tatham, R. (2010). Multivariate data analysis. New Jersey: Prentice Hall.

Hair Jr, J. F., Hult, G. T. M., Ringle, C., \& Sarstedt, M. (2014). A primer on partial least squares structural equation modelling (PLS-SEM). Sage publications.
Hall, J., Daneke, G., \& Lenox, M. (2010). Sustainable development and entrepreneurship: Past contributions and future directions. Journal of Business Venturing, 25(5), 439-448.

https://doi.org/10.1016/j.jbusvent.2010.01.002

Joo, J., \& Shin, M. (2017). Building sustainable business ecosystems through customer participation: A lesson from South Korean cases. Asia Pacific Management Review, 23(1), 1-11. https://doi.org/10.1016/j.apmrv.2017.01.001

Joshi, A., \& Sharma, S. (2004). Customer knowledge development: antecedents and impact on new product performance. Journal of Marketing, 68(10), 47-59.

https://doi.org/10.1509/jmkg.68.4.47.42722

Klein, J. (1999). The relationship between level of academic education and reversible and irreversible processes of probability decision-making. Higher Education, 37(4), 323-339.

https://doi.org/10.1023/A:1003608412240

Lagrosen, S. (2005). Customer involvement in new product development: a relationship marketing perspective. European Journal of Innovation Management, 8(4), 424-436. https://doi.org/10.1108/14601060510627803

Lee, S., Olson, D., \& Trimi, S. (2012). Co-innovation: convergenomics, collaboration, and co-creation for organizational values. Management Decision, 50(5), 817-831. https://doi.org/10.1108/00251741211227528

Lendel, V., \& Varmus, M. (2013). Use of innovation in marketing management of Slovak business enterprises. Business: Theory and Practice, 14, 35. https://doi.org/10.3846/btp.2013.04

Lüdeke-Freund, F. (2013). Business model for sustainability innovation: conceptual foundation and the case of solar energy (PhD's Thesis). Lüneburg: Leuphana Universität Lüneburg.

Magretta, J. (2002). Why business models matter. Massachusetts: Harvard Business Review.

Merlo, O., Eisingerich, A., \& Auh, S. (2014). Why customer participation matters. MIT Sloan Management Review, 55(2), 81. Massachusetts: MIT Sloan Management Review.

Merx-Chermin, M., \& Nijhof, W. (2005). Factors influencing knowledge creation and innovation in an organisation. Journal of European Industrial Training, 29(2), 135-147.

https://doi.org/10.1108/03090590510585091

Ministry of Commerce and Industry of the Republic of India. (2017). Notification G.S.R. 501 (E). http://www.egazette.nic. in/WriteReadData/2017/176201.pdf

Muhamad, M., Ebrahim, Z., \& Hami, N. (2014, 7-9 January). The Influence of innovation performance towards manufacturing sustainability performance. In Proceeding of 2014 International Conference on Industrial Engineering and Operations Management. Bali.

Mustak, M., Jaakkola, E., \& Halinen, A. (2013). Customer participation and value creation: a systematic review and research implications. Managing Service Quality: An International Journal, 23(4), 341-359.

https://doi.org/10.1108/MSQ-03-2013-0046

Osterwalder, A. (2004). The business model ontology a proposition in a design science approach (Doctoral dissertation). Université de Lausanne, Faculté des hautes études commerciales.

Plé, L., Lecocq, X., \& Angot, J. (2010). Customer-integrated business models: a theoretical framework.M@n@gement, 13(4), 226-265. https://doi.org/10.3917/mana.134.0226

Prahalad, C., \& Ramaswamy, V. (2004). Co-creating unique value with customers. Strategy \& Leadership, 32(3), 4-9. https://doi.org/10.1108/10878570410699249

Rademakers, M. (2005). Corporate universities: driving force of knowledge innovation. Journal of workplace Learning, 17(1/2), 130-136. https://doi.org/10.1108/13665620510574513 
Rahman, S. A., Taghizadeh, S. K., Ahmad, N., \& Ramayah, T. (2016). Psychological factors of innovativeness among nomadic micro-entrepreneurs for achieving business growth. Business: Theory and Practice, 17, 191. https://doi.org/10.3846/btp.2016.618

Redis, J. (2009). The impact of business model characteristics on IT firms' performance. International Journal of Business, 14(4), 291.

Santos, J., \& Brito, L. (2012). Toward a subjective measurement model for firm performance. BAR-Brazilian Administration Review, 9(SPE), 95-117. https://doi.org/10.1590/S1807-76922012000500007

Schaltegger, S., \& Wagner, M. (2011). Sustainable entrepreneurship and sustainability innovation: categories and interactions. Business Strategy and the Environment, 20(4), 222-237. https://doi.org/10.1002/bse.682

Schaltegger, S., Lüdeke-Freund, F., \& Hansen, E. (2012). Business cases for sustainability: the role of business model innovation for corporate sustainability. International Journal of Innovation and Sustainable Development, 6(2), 95-119. https://doi.org/10.1504/IJISD.2012.046944

Shah, R., \& Goldstein, S. (2006). Use of structural equation modeling in operations management research: Looking back and forward. Journal of Operations Management, 24(2), 148-169. https://doi.org/10.1016/j.jom.2005.05.001

Sinfield, J., Calder, E., McConnell, B., \& Colson, S. (2012). How to identify new business models. MIT Sloan Management Review, 53(2), 85. Massachusetts: MIT Sloan Management Review.

Teece, D. (2007). Explicating dynamic capabilities: the nature and microfoundations of (sustainable) enterprise performance. Strategic Management Journal, 28(13), 1319-1350. https://doi.org/10.1002/smj.640
Teece, D. (2010). Business models, business strategy and innovation. Long Range Planning, 43(2), 172-194. https://doi.org/10.1016/j.lrp.2009.07.003

Teeratansirikool, L., Siengthai, S., Badir, Y., \& Charoenngam, C. (2012). Competitive strategies and firm performance: the mediating role of performance measurement. International Journal of Productivity and Performance Management, 62(2), 168-184. https://doi.org/10.1108/17410401311295722

Timmers, P. (1998). Business models for electronic markets. Journal of Electronic Markets, 8, 3-8. https://doi. org/10.1080/10196789800000016

United Nations. (1987). Our common future: report of the world commission on environment and development (Report No. A/42/427). https://sswm.info/sites/default/files/ reference_attachments/UN\%20WCED\%201987\%20Brundtland\%20Report.pdf

Wijnker, M., Van Kasteren, H., \& Romijn, H. (2015). Fostering sustainable energy entrepreneurship among students: The business oriented technological system analysis (BOTSA) program at Eindhoven university of technology. Sustainability, 7(7), 8205-8222. https://doi.org/10.3390/su7078205

Zott, C., \& Amit, R. (2001). Value creation in e-business. Strategic Management Journal, 22(6-7), 493-520. https://doi.org/10.1002/smj.187

Zott, C., \& Amit, R. (2007). Business model design and the performance of entrepreneurial firms. Organization Science, 18(2), 181-199. https://doi.org/10.1287/orsc.1060.0232 